\title{
Towards Zero Waste in Steel Industry: Polish Case Study
}

\section{Marzena Smol*}

The Mineral and Energy Economy Research Institute, Polish Academy of Sciences, Kraków, Poland

\begin{abstract}
Poland is one of the most important producers of raw steel and steel products in Europe. During the past decade a considerable number of companies in steel sector in Poland efforts to reduce their impact on the environment, applying the principles of cleaner production (CP). The restructuring of the industry and implementation new eco-technologies caused an increase in share of material recycling, including steel scrap recovered in production processes and from post-use recycling. Depending on the type of steel waste, it can be returned to the process as energy source or raw material for steel fabrication or else be traded as co-product to other industrial applications. The reuse of these products is of great importance for the sector owing to economical and environmental aspects Such directions of steel waste utilization are consistent with the 'zero waste' strategy and they should be further investigated in Polish conditions, taking into account the possibilities of development, modernization and construction of new installations. These eco-technologies will be especially supported by European funds in new programming period 2014-2020.
\end{abstract}

Keywords: Steel industry; Circular economy (CE); ZERO waste

\section{Introduction}

In recent years, unsustained mining practices have led to exploitation of natural resources causing extensive environmental degradation [1]. Moreover, continually increasing demand for metals, declining ore grades and complex new deposits are all contributing to a rise in greenhouse gas (GHG) emissions from primary metal production. The consequence of this is fact that the mineral processing and metal production sector is coming under increasing pressure to improve the overall sustainability of its operations, especially by decreasing energy consumption, GHG emissions and waste disposal [2].

Global environmental compliance is an important objective in corporate activities [3]. Government institutions and enterprises have taken various initiatives to contribute to sustainable development. It is associated with the moving towards a more circular economy (CE). The concept of a circular economy has been first raised by British environmental economists Pearce and Turner in 1990, who pointed out that a traditional open-ended economy was developed with no built-in tendency to recycle, which was reflected by treating the environment as a waste reservoir [4]. The aim of circular economy is to reduce the resources so that the system functions function in an optimal way. An important advantage of circular economy systems is to keep the added value of products for as long as possible and eliminate waste ('zero waste'). To keep resources within the economy when a product has reached the end of its life to productively use it again and hence create further value [5]. Transition to a more circular economy requires full systemic change, and innovation in organization, society, policies, technologies and finance methods. Currently, the concept of CE is introduced to the management strategy of many companies worldwide [6]. The metallurgical industry (including iron and steel sector) is one of the basic industries and generates large quantities of waste (e.g. in 2008, the annual generation of solid waste of iron and steel industry was about $31 \%$ of the total industrial sectors in China). An introduction of new technological solutions aimed at waste recycling in this sector is important and necessary.

\section{Life Cycle of Steel}

Steel is a metal alloy that is composed principally of iron, carbon, and other elements (small amounts of manganese, silicon, phosphorous, oxygen, sulfur, etc.) with high tensile strengths and low costs. The life cycle of steel is presented in Figure 1.

The main stages of steel contribute to the environment include:

- $\quad$ Steel manufacture from raw materials;

- $\quad$ Fnish steel product;

- Fabrication and assembly of final steel products;

- Use of final products;

- $\quad$ Scrapping or recycling for reuse [3].

During the production of steel, integrated steel plants utilize mostly five materials as raw materials, air, water, fuel and power. It is worth noting that steel production can occur at an integrated facility from both iron ore and at a secondary facility, which produces steel mainly from recycled steel scrap [7]. Raw steel is widely used in the construction industry and other engeenering applications, using a variety of rolled products (sheets, zinc-plated sheets, tin-plated sheets, cold rolled bands, steel pipes, sheet-metal sections, etc.) and forged or drawn products (bars, wires).

In recent years, more and more attention is paid to the concept of a life cycle approach for sustainability of products and services. It is associated with product lifecycle management (PLM) which is a system for overseeing manufacturing processes, from the design and development of a product to its ultimate disposal. This strategy aims at taking into account sustainability impacts (environmental, economic, social) that a product or service will have throughout its life cycle from 'cradle to grave' [2]. Industrial sustainability is the ultimate goal

*Corresponding author: Marzena Smol, The Mineral and Energy Economy Research Institute, Polish Academy of Sciences, Kraków, Poland, Tel: (+48) 12-617-16-33; E-mail: smol@meeri.pl

Received September 01, 2015; Accepted October 05, 2015; Published October 12,2015

Citation: Smol M (2015) Towards Zero Waste in Steel Industry: Polish Case Study. J Steel Struct Constr 1: 102. doi:10.4172/2472-0437.1000102

Copyright: (c) $2015 \mathrm{Smol} \mathrm{M}$. This is an open-access article distributed under the terms of the Creative Commons Attribution License, which permits unrestricted use, distribution, and reproduction in any medium, provided the original author and source are credited. 


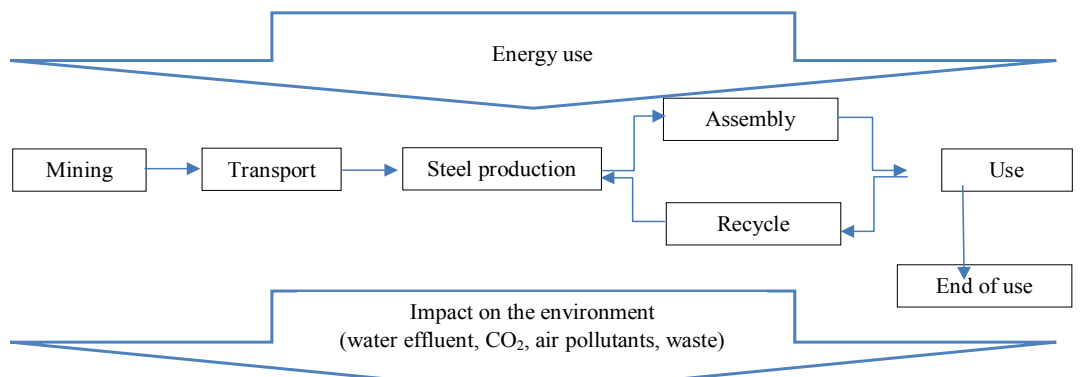

Figure 1: Life cycle of steel.

Source: Own study based on Kawai [3].

\begin{tabular}{|c|c|c|c|c|c|c|c|c|c|c|}
\hline \multirow[t]{2}{*}{ Year } & \multicolumn{2}{|c|}{2009} & \multicolumn{2}{|c|}{2010} & \multicolumn{2}{|c|}{2011} & \multicolumn{2}{|c|}{2012} & \multicolumn{2}{|c|}{2013} \\
\hline & '000 Mg & $\%$ & '000 Mg & $\%$ & ‘000 Mg & $\%$ & ‘000 Mg & $\%$ & ‘000 Mg & $\%$ \\
\hline Production & 7,128 & - & 7,996 & - & 8,777 & - & 8,539 & - & 8,199 & - \\
\hline From electric arc furnace & 3,893 & 54.6 & 4,001 & 50.0 & 4,353 & 49.6 & 4,206 & 49.3 & 3,679 & 44.9 \\
\hline From converters & 3,235 & 45.4 & 3,995 & 50.0 & 4,424 & 50.4 & 4,333 & 50.7 & 4,520 & 55.1 \\
\hline Imports & 7 & 33.3 & 1 & 4.5 & 1 & 3.7 & 1 & 4.0 & 1 & 3.6 \\
\hline Exports & 12 & 57.1 & 21 & 95.5 & 26 & 96.3 & 24 & 96.0 & 27 & 96.4 \\
\hline Consumption & 7,129 & - & 7,976 & - & 8,752 & - & 8,516 & - & 8,173 & - \\
\hline
\end{tabular}

Table 1: Crude steel statistics in Poland - CN 7206.

\begin{tabular}{|c|c|c|c|c|c|}
\hline Year & 2009 & 2010 & 2011 & 2012 & 2013 \\
\hline Hot rolled rails & 164.3 & 259.8 & 245.9 & 157.6 & 176.4 \\
\hline Hot rolled bars and sections & $4,102.4$ & $4,533.9$ & $4,906.1$ & $3,441.9$ & $3,457.7$ \\
\hline Hot rolled sheets & $1,917.6$ & $2,113.3$ & $2,295.6$ & $1,969.2$ & $2,120.9$ \\
\hline Cold rolled sheets & 557.7 & 834.7 & 806.6 & $1,353.5$ & $1,459.7$ \\
\hline Cold rolled galvanized sheets & 395.9 & 455.2 & 453.1 & 676.3 & 914.0 \\
\hline Cold rolled roll-formed sections & 531.5 & 545.4 & 596.8 & 577.9 & 494.5 \\
\hline Pipes & 346.5 & 383.7 & 407.8 & 592.2 & 607.4 \\
\hline Wires & 213.6 & 258.0 & 197.5 & 186.0 & 211.9 \\
\hline
\end{tabular}

Table 2: Production of the main steel products in Poland.

of modern society $[8,9]$, particularly so for the iron and steelmaking industries. Sustainable steelmaking goals were defined by Fruehan (9) as:

- Conservation of natural resources (ore, coal, etc.)

- Reduction of greenhouse gas emissions

- Reduction of volatile emissions

- Reduction of landfill waste

- Reduction of hazardous waste

Steel production is one of the most important and fundamental industrial processes [10]. Steel is characterized by extremely high susceptibility to recycling, the whole life cycle of steel. Secondary steel usage should also be considered. In the process of reuse, it retains all its natural properties like very high durability and strength. Steel recycling is a way of huge savings of energy and raw materials.

\section{Steel Production in Poland}

Poland is one of the most important producers of raw steel and steel products in Europe. There are 17 active steelworks producing raw steel and/or steel products. The steel production plants are located in the Upper Silesia. Only five steelworks are located outside of this region, i.e. ArcelorMittal plant in Kraków, ISD Częstochowa, CELSA
Huta Ostrowiec, Stalowa Wola, and Arcelor Warszawa in Warsaw [11].

In the last years, the production of raw steel varied widely (Table 1). In 2009, the steel production was the smallest, equal to $7,128,000 \mathrm{Mg}$. The share of production from electric arc furnace and from oxygenblown converters remains at the same level (approximate 50\%). Crude steel breakdown by grades has been stable in recent years. Crude steel melted in Poland, low-alloy represented around 93.6\%, while high-alloyed accounted for about $6.4 \%$ and stainless steel production is very marginal. For example in 2013 stainless steel amounted to only $0.02 \%$ [11]. Currently, only $3.6 \%$ of steel is imported, and more than $96 \%$ is exported. This confirms a significant position of Poland in the international market.

In Poland, the most important final products of steel are hot and cold rolled products, pipes, bars, and wires. The production of the main steel products in 2009-2013 is presented in Table 2. The steel production has been characterized by a high proportion of hot rolled bars, sections, and semis. One negative feature, in discordance with world trends, is still inadequate production of hot rolled sheets, and slow increase of production of galvanized sheets [11].

Presently, steel products are among Poland's main export commodities. The list of the most important companies involved in iron and steel production in Poland includes: 
- Andrzej Tube Mill Ltd. of Zawadzkie - pipes and tubes.

- Bankowa Steelworks Ltd. of Dąbrowa Górnicza - hot rolled products.

- Batory Steelworks Ltd. of Chorzów - raw steel, special steels, pipes, tubes.

- Severstallat Silesia Steelworks Ltd. of Sosnowiec - pipes, tubes, rolls.

- Arcelor Mittal Poland S.A., Unit in Krakow - steel making pig iron, raw steel, hot rolled.

- Products, cold rolled products, pipes, cast iron, tinplated sheets, galvanized sheets.

- Arcelor Mittal Poland S.A., Unit in Dabrowa Gornicza steelmaking pig iron, raw steel, hot rolled products, cast steel.

- ArcelorMittal Poland S.A., Unit in Swietochlowice - raw steel, hot rolled products, galvanized sheet, cold rolled strip.

- Arcelor Mittal Poland S.A., Unit in Sosnowiec - hot rolled products, cold rolled strip, cast iron.

- ISD Częstochowa Steelworks - steel making and foundry pig iron, raw steel, hot rolled sheets, pipes, cast iron.

- FERROSTAL Łabędy Ltd. of Gliwice - raw steel, semi-finished hot rolled products, bars.

- Ferrum Steelworks Joint Stock Co. of Katowice - pipes.

- Królewska Steelworks Ltd. of Chorzów - hot rolled products, rails, bars.

- Arcelor Huta Warszawa Steelworks Ltd. of Warsaw - raw steel, special steels, hot rolled products, cold rolled strip.

- $\quad$ Łabędy Steelworks Joint Stock Co. of Gliwice - rolled products.

- CELSA Huta Ostrowiec Steelworks Ltd. of Ostrowiec Świętokrzyski - raw steel, rods, hot rolled products.

- Pokój Steelworks Joint Stock Co. of Ruda Śląska - hot rolled products, rails.

- Stalowa Wola Steelworks Joint Stock Co. - raw steel, hot rolled products, cold rolled sheet.
- Zabrze Steelworks Joint Stock Co. of Zabrze - raw steel, cast iron, cast steel.

- CMC Zawiercie Steelworks Joint Stock Co. of Zawiercie - raw steel, hot rolled products, cast iron, cast steel [11].

In 2014 the steel industry worked 106 entities, including 24 manufacturers of steel products. The number of workers employed in the sector amounted to 30,131 people, of which the production of steel products 20,475 . Revenues of steel companies exceeded 7.8 billion EUR (30.7 billion PLN), and for steel products amounted to nearly 6.1 billion EUR (24.3 billion zł). Capital expenditures have a value of 187.5 million EUR (750 million $\mathrm{z}$ ), including the manufacture of steel products - 135 million EUR (540 million zł). In January-May 2015, crude steel production in Poland amounted to nearly 4,077 million Mg. It is an increase $16 \%$ compared to the same period in 2014 . There is also an increase in consumption of steel products. Consumption of steel products in Poland in 2014 reached 12.2 million $\mathrm{Mg}$, and it was $17 \%$ more than in 2013. Furthermore, in 2020, the government predicts that steel consumption will increase to 20 million $\mathrm{Mg}$. This means that the steel industry is very important for the Polish economy - it is one of the key industries and has an impact on other industry sectors, ie. Energy, Transport and Construction.

\section{Waste Steel Disposal Practices}

The restructuring of the Polish industry and implementation new technology cause that more and more modern products with advanced technical and functional parameters are obtained from domestic production, which results in an increase in efficient use of these materials. The share of material recycling, including steel scrap and non-ferrous metal scrap, recovered in production processes and from post-use recycling becomes more and more important for supply [12].

Currently, in materials management raw materials and materials obtained from recycling are of growing importance. Many mineral materials, including metals, return to the production process in the form of secondary-raw materials. In the metallurgical industry, steel is most recycled and important material, as illustrated in Figure 2 [13]. In the case of metallic wastes, the amount of steel and iron waste suitable for recycling in 2013 in Poland was equal to 4,068,949 Mg (Figure 2), wherein the sum of the other metallic waste was $445,788 \mathrm{Mg}$ (copper $235,236 \mathrm{Mg}$; lead, zinc and tin - 22,379 Mg; aluminium - 188,173 Mg).

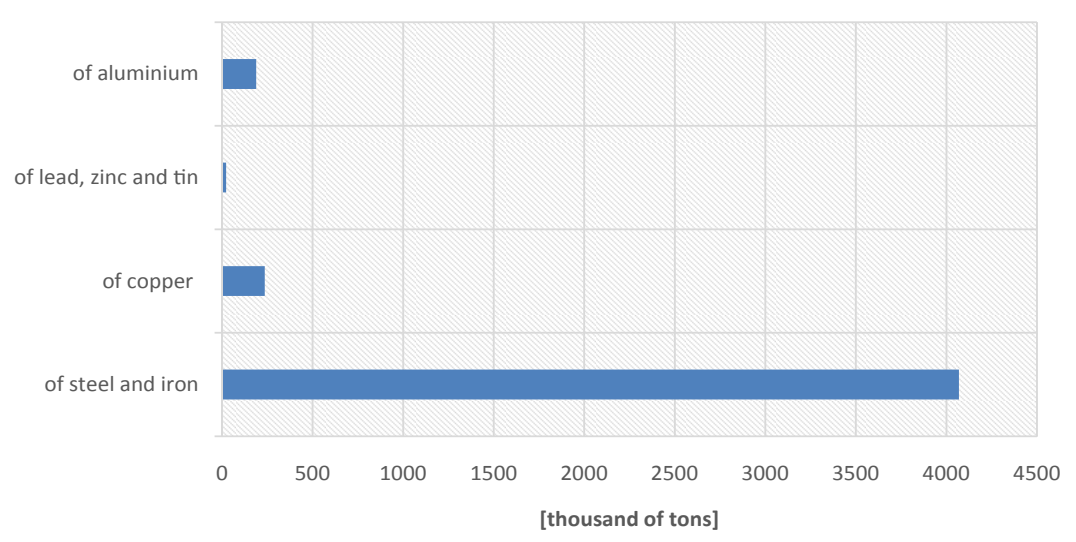

Source: Own study based on GUS [11].

Figure 2: Total tons of metallic wastes suitable for recycling in Poland in 2013. 


\begin{tabular}{|c|c|c|c|c|c|c|c|c|c|}
\hline \multirow[b]{3}{*}{ Year } & \multicolumn{4}{|c|}{ Supply } & \multicolumn{5}{|c|}{ Use } \\
\hline & \multicolumn{9}{|c|}{ [Mg] } \\
\hline & Total & $\begin{array}{l}\text { From own } \\
\text { activity }\end{array}$ & Procu-rement & Import & Total & $\begin{array}{c}\text { Self- } \\
\text { consum-ption }\end{array}$ & Domestic sales & Export & $\begin{array}{l}\text { Natural } \\
\text { losses }\end{array}$ \\
\hline 2012 & $5,933,114$ & 974,365 & $4,624,848$ & 333,901 & $5,938,136$ & $5,618,577$ & 191,400 & 1,404 & 126,755 \\
\hline 2013 & $5,801,212$ & $2,174,173$ & $3,626,558$ & 481 & $5,611,521$ & $2,061,272$ & $3,426,203$ & 112,162 & 11,884 \\
\hline
\end{tabular}

Source: GUS [11].

Table 3: Scrap and metallic waste of steel and iron suitable for recycling.

The utilization of waste causes that demand for materials in industrialized countries has increased slower than production. The use of waste obtained from production processes and also obtained from procurement is more and more important in Poland for ecological and economical reasons. This is combined with the protection of natural environment and reduction of energy consumption by production processes, which involves an increase in use of waste that is a source of cheap and pro-ecological materials. This concern among others scrap and waste steel, non-ferrous metals (copper, aluminum, lead, zinc and tin). Moreover, acquisition of metals from waste materials consumes less energy than acquisition from original sources [12]. The amount of scrap and metallic waste of steel and iron suitable for recycling in 2012 and 2013 in Poland is shown in Table 3.

Compared to the previous year, in 2013 the amount of scrap and metallic waste of steel and iron coming from own activity was more than two times higher. Attention was drawn to a more sustainable use of waste and recycles the processes in plants. At the same time, the volume of imports in total amount of supply dropped significantly, from 333,901 Mg in 2012 to $481 \mathrm{Mg}$ in 2013.

During steel production processes large amounts of waste (solid wastes, liquid effluents and gaseous emissions) is generated, practically at each stage of steelmaking: $2-4 \mathrm{Mg}$ of waste is being generated per tonne of steel produced [14]. According to 'zero waste', strategy waste generated in the steel-making sector need to be improved. In the steel works, four groups of solid waste should be mentioned:

- $\quad$ Steel slag

- Scale

- $\quad$ Scrap metal

- $\quad$ Dusts and sludges

Depending on the type of waste, it can be returned to the process as energy source or raw material for steel fabrication or else be traded as co-product to other industrial applications. The reuse of these products is of great importance for the sector regarding both economical and environmental aspects [15].

Steel slag is a post-metallurgical waste arising from the manufacture of steel. It contains $4-11 \%$ metal components which after recovering could be reused as scrap metal batch ready for immediate use in the steelmaking process. Slag is a valuable waste which can be used in agriculture, environment processes and construction industry (in road construction eg. road stabilization of subsoil, dehydration, embankments, etc.), as a substitute for fluxes, and finer fractions can be used for the production of cement. It could be also used in infrastructure because the presence of steel increased the density of hardened concrete Other properties such as porosity, water holding capacity, bulk density make the slag suitable for using as adsorbent [16]. In Poland, practically all of formed steel slag is directed to the use by outside companies, mainly in road construction.
Cement with the addition of metallurgical slag is resistant to sea water (granulated slag), as thermal and acoustic insulation (metallurgical pumice, slag wool) [17]. In contrast, steelmaking slag with basicity much greater than $1.1-1.2\left(\mathrm{CaO} / \mathrm{SiO}_{2}\right)$ is used in agriculture as a fertiliser, the substance with de-acidifying ground properties and for treatments for soil improvement [16].

Scale is the product of oxidation of the surface of steel products during their high temperature plastic processing (eg. rolling, forging, extrusion). Scale is mainly a mixture of iron oxides at a different oxidation state and trace amounts of other metal oxides, which are admixture of converted steel. It is one of the most valuable secondary raw materials of iron and currently it is transferred to external customers for reuse.

Scrap metal is an important raw material for steel making in the secondary market. Iron present in the metallic form, requires only melting and final refining processes to obtain the full value of the product as a specific grade of steel.

Recycling of dust and sludges becomes possible only after overcoming technological problems related to giving them forms allowing their use as feed material. It is required to change this waste into the form of granules with sufficient strength, eg. Dust recycling is realized as outside recycling in cement plants, or at the plant, dust is recirculated to the process in an electric furnace [17]. It is estimated that during steel production in electric furnaces approx. $1-2 \%$ of the metallic charge is converted to dust. A limitation of dust full re-use is its variable composition and the high cost of implementing new technologies of recycling. The cost of storing $1 \mathrm{Mg}$ of dust may account for $50 \%$ of the price of $1 \mathrm{Mg}$ of steel rods. These dusts cannot be stored in open landfills [18].

Currently, the main environmental benefits associated with various methods of recycling in the steel industry is saving natural resources, reduction of greenhouse gases $\left(\mathrm{CO}_{2}, \mathrm{SO}_{2}\right)$, space in landfills and energy savings [18]. Zwolińska et al. [19] have stated that there is a possibility of maximum recycling to the economic circulation and reuse of practically all elements included in waste but it requires significant financial investments and access to the right technologies, under Polish conditions. In Poland, there are a consultation points where all entrepreneurs, including steelworks can obtain information about current programs, supporting the development of cleaner production (CP) technologies under the EU Research and Innovation Programme (Horizon 2020) and its instruments, including the European Institute of Innovation and Technology, the European Structural and Investment Funds, the Eco-innovation Action Plan, the Green Action Plan for small and medium-sized enterprises (SMEs), and the European Consumer Agenda [12]. The steel companies should be aware that it is required to take into account whole life cycle in the investments projects, in accordance with the 'zero waste' strategy. These solutions will be in the first place supported by European funds at the national and international level in new programming period 2014-2020. 
Moreover, all activities should be consistent with the Best Available Techniques [17] which is a principle defined in the EU directive on Integrated Pollution Prevention and Control (IPPC) (2008/1/EC). The purpose of the IPPC is to prevent and control pollution from various sectors, such as steel and iron industry. In the European Union the most significant source of pollution in the steel industry are sinter plants [20]. As Best Available Techniques in steelworks, the following solutions are recommended:

- Dedusting gases by the use of advanced electrostatic precipitation, electrostatic precipitation plus fabric filter, the initial dust removal, high-pressure water scrubbing system.

- Recirculation of exhaust gases from all or part of the surface of the sinter strand.

- Reduction of emissions of polychlorinated dibenzodioxins and polychlorinated furans through the use of exhaust gas recirculation, utilization of waste gases from the sinter strand, the use of scrubbing.

- $\quad$ Reduction of emissions of heavy metals through the use of wet scrubbing system to remove heavy metal chlorides dissolved in water, especially of lead chloride over $90 \%$ yield, or by using a bag filter containing lime.

- Reduction of hydrocarbon content in the mixture sinter, the oil content in recycled by-products should not exceed $0.1 \%$.

- Recovering sensible heat from waste gases from the sinter cooler.

- Minimization of $\mathrm{SO}_{2}$ emissions by lowering the amount of sulfur introduced into the sinter mix; by the use of such agents it is possible to achieve $\mathrm{SO}_{2}$ emissions lower than $1 \mathrm{~kg} / \mathrm{Mg}$ sinter, while using wet flue-gas desulfurization, reduction of $\mathrm{SO}_{2}$ could be more than $98 \%$.

- Minimization of NOx emissions by recirculating exhaust gas, the use of flue gas denitrification (nitrogen removal from the flue gases), the process of regeneration of activated carbon, selective catalytic reduction [17].

In Poland, during the past decade a considerable number of companies in the steel industrial sector made efforts to reduce their impact on the environment, applying the principles of cleaner production. Modernization were continued at several steel companies, i.e. ArcelorMittal Poland has commissioned a new caster and a tundish, and has modernized blast furnace; ArcelorMittal Warszawa has commissioned new bar mill; Celsa Huta Ostrowiec modernized caster anelectric arc furnance; ISD Huta Częstochowa has commissioned three chamber furnaces for plate heat treatment and modernized Heavy Plate Mill's furnace; and CMC Zawiercie commissioned a new rod mill. Moreover, two new hot rolling mills for long products were launched (in Celsa Huta Ostrowiec and in CMC Zawiercie) and cold rolling mill for thin sheets was upgraded (in ArcelorMittal Poland Unit in Kraków). Thanks to these investments steel plants extended and improved their product range, which provided the customers with a comprehensive range of technologically advanced products [11]. Moreover, the steel companies are aware that an important factor owing to which enterprises are competitive on the national and international markets is an introduction of $\mathrm{CP}$ technologies, including waste disposal.

\section{Conclusions}

In the last years, in Poland a significant limitation of the negative influence of enterprises from steel metallurgical sector on the natural environment was observed. This follows from application of innovative, low-waste solutions of technical and technological type and application in production of steel of materials achieved during waste recycling and utilization in other branches of industry, eg. construcion industry (road engineering). The conducting of manufacturing processes in a way ensuring maximum respect for and protection of the environment should be one of the most important principles of plant operation for all steelworks. Under this principle, the company should therefore seek to:

- Maximize the use of available technology to reduce environmental impact [17].

- Optimal management of raw materials to reduce their consumption.

- Waste minimization and its full disposal.

- Minimize emission of substances and gases into the air and soil.

An efficient (integrated) management system, in accordance to the 'zero waste' strategy, is the key to success in environmental policy in the steel industry. There are several programs, such as environmental management in accordance with ISO 14001 or program cleaner production (CP), which companies can implement in their operation of. All these systems are designed to facilitate companies to implementation of the principles of environmental protection and efficient waste management whose objective is to minimize the negative impact of businesses on environment.

\section{References}

1. Raghupathy L, Chaturvedi A (2013) Secondary resources and recycling in developing economies. Science of the Total Environment 461: 830-834.

2. Norgate T, Jahanshahi S (2011) Reducing the greenhouse gas footprint of primary metal production: Where should the focus be? Minerals Engineering 24: $1563-1570$.

3. Kawai J (2001) Development of environmentally-conscious steel products at the Nippon Steel Corporation. Materials and Design 22: 111-122.

4. Su B, Heshmati A, Geng Y, Yu X (2013) A review of the circular economy in China: moving from rhetoric to implementation. Journal of Cleaner Production 42: $215-227$

5. Smol M, Kulczycka J, Henclik A, Gorazda K, Wzorek Z (2015) The possible use of swage sludge ash (SSA) in the construction industry as a way towards a circular economy. Journal of Cleaner Production 95: 45-54.

6. Wübbeke J, Heroth T (2014) Challenges and political solutions for steel recycling in China. Resources, Conservation and Recycling 87: 1-7.

7. Yellishetty M, Mudd GM, Ranjith PG, Tharumarajah A (2011) Environmental life-cycle comparisons of steel production and recycling: sustainability issues, problems and prospects. Environmental Science and Policy 14: 650-663.

8. Strezov V, Evans A, Evans T (2013) Defining sustainability indicators of iron and steel production. Journal of Cleaner Production 51: 66-70.

9. Fruehan RJ (2009). Research on sustainable steelmaking. Metallurgical and Materials Transactions B 40: 123-133.

10. Bo C, Yang JX, Ouyang ZY (2011) Life cycle assessment of internal recycling options of steel slag in Chinese iron and steel industry. Journal of Iron and Steel Research International 18: 33-40.

11. (2013) The Central Statistical Office (GUS), Warsaw. Minerals Yearbook of Poland.

12. (2014) Commission of European Communities. Towards a circular economy: A zero waste programme for Europe.

13. Singh RK, Murty HR, Gupta SK, Dikshit AK (2007) Development of composite sustainability performance index for steel industry. Ecological Indicators 7: 565588. 
14. Das B, Prakash S, Reddy PSR, Misra VN (2007) An overview of utilization of slag and sludge from steel industries. Resources conservation and recycling 50: 40-57.

15. Vieira CMF, Andrade PM, Maciel GS, Vernilli F, Monteiro SN (2006) Incorporation of fine steel sludge waste into red ceramic. Materials Science and Engineering A 427: 142-147.

16. Barbuta M, Bucur RD, Cimpeanu SM, Paraschiv G, Bucur D (2015) Wastes in Building Materials Industry.
17. (2005) Best Available Techniques (BAT) Guidelines for the Production of Steel Electric Steelworks with Steel Casting, Ministry of the Environment, Warsaw.

18. Maj M, Kalendyk B, Zapała R (2010) Modern recycling methods in metallurgical industry. Archives of Foundry Engineering 19: 103-106.

19. Zwolińska B, Michlowicz E, Kisiel P (2012) Types of waste streams created in steelworks with full production cycle. Hutnik, Wiadomości Hutnicze 79: 817-821.

20. Dulęba A (2013) Manufacturing waste in the steel industry Hutnictwo Odlewnictwo. 